\title{
Antibacterial effect of calcium hydroxide combined with chlorhexidine on Enterococcus faecalis: systematic review and meta-analysis
}

\author{
Masoud SAATCHI ${ }^{1}$, Ali SHOKRANEH ${ }^{1}$, Hooman NAVAEI ${ }^{2}$, Mohammad Reza MARACY ${ }^{3}$, Hasan SHOJAEI ${ }^{4}$ \\ 1- Torabinejad Dental Research Center, Department of Endodontics, School of Dentistry, Isfahan University of Medical Sciences, Isfahan, Iran. \\ 2- Torabinejad Dental Research Center, School of Dentistry, Isfahan University of Medical Sciences, Isfahan, Iran. \\ 3- Department of Biostatistics and Epidemiology, School of Public Health, Isfahan University of Medical Sciences, Isfahan, Iran. \\ 4- Department of Microbiology, School of Medicine, Isfahan University of Medical Sciences, Isfahan, Iran.
}

Corresponding address: Ali Shokraneh - Department of Endodontics, School of Dentistry, Isfahan University of Medical Sciences, Isfahan, Iran. Zip Code: 8174755153 - Phone: +98-311-7922846 - Fax: +98-311-6687080 - e-mail: ali_shokrane@dnt.mui.ac.ir

Submitted: January 24, 2014 - Modification: April 30, 2014 - Accepted: May 15, 2014

\section{ABSTRACT}

\begin{abstract}
O bjective: Enterococcus faecalis (E. faecalis) is the most frequently isolated strain in failed endodontic therapy cases since it is resistant to calcium hydroxide $(\mathrm{CH})$. Whether a combination of $\mathrm{CH}$ and chlorhexidine $(\mathrm{CHX})$ is more effective than $\mathrm{CH}$ alone against $\mathrm{E}$. faecalis is a matter of controversy. Thus, the aim of this study was to conduct a systematic review and meta-analysis of the literature. Material and Methods: A comprehensive search in PubMed, EMbase, EBSCOhost, The Cochrane Library, SciELO, and BBO databases, Clinical trials registers, Open Grey, and conference proceedings from the earliest available date to February 1, 2013 was carried out and the relevant articles were identified by two independent reviewers. Backward and forward search was performed and then inclusion and exclusion criteria were applied. The included studies were divided into "comparisons" according to the depth of sampling and dressing period of each medicament. Meta-analysis was performed using Stata software 10.0. The level of significance was set at 0.05. Results: Eighty-five studies were retrieved from databases and backward/forward searches. Fortyfive studies were considered as relevant ( 5 in vivo, 18 in vitro, 18 ex vivo, and 4 review articles). Nine studies were included for meta-analysis. Inter-observer agreement (Cohen kappa) was 0.93 . The included studies were divided into 21 comparisons for meta-analysis. Chi-square test showed the comparisons were heterogeneous $(p<0.001)$. Random effect model demonstrated no significant difference between $\mathrm{CH} / \mathrm{CHX}$ mixture and $\mathrm{CH}$ alone in their effect on $E$. faecalis $(p=0.115)$. Conclusions: According to the evidence available now, mixing $\mathrm{CH}$ with $\mathrm{CHX}$ does not significantly increase the antimicrobial activity of $\mathrm{CH}$ against E. faecalis. It appears that mixing $\mathrm{CH}$ with $\mathrm{CHX}$ does not improve its ex vivo antibacterial property as an intracanal medicament against $E$. faecalis. Further in vivo studies are necessary to confirm and correlate the findings of this study with the clinical outcomes.
\end{abstract}

Keywords: Products with antimicrobial action. Calcium hydroxide. Chlorhexidine. Enterococcus faecalis. Meta-analysis.

\section{INTRODUCTION}

Microbial invasion of the root canal system has an important role in initiating and sustaining periapical disease $^{41}$. The aim of root canal therapy is to eliminate bacteria and their by-products from the root canal system ${ }^{74}$. Although chemomechanical cleaning and shaping of the canal is effective in reducing bacterial counts, microorganisms may persist in the anatomical complexities of root canal system and increase the risk of treatment failure ${ }^{12,109}$. Therefore, intracanal medication is advocated to further reduce bacteria in the root canal system and increase the success of root canal treatment ${ }^{11}$. 
Calcium hydroxide $(\mathrm{CH})$ is the most commonly used intracanal medicament in endodontics ${ }^{93}$. It dissociates into calcium and hydroxyl ions in an aqueous solution. The antimicrobial property of $\mathrm{CH}$ is attributed to the release of hydroxyl ions and provides a highly alkaline environment with a $\mathrm{pH}$ value of approximately $12.5^{93,101}$. Most of the microorganisms in infected root canals are unable to survive in the alkaline environment ${ }^{37}$. However, $\mathrm{CH}$ is not equally effective against all the bacteria found in the root canal70.

Chlorhexidine gluconate $(\mathrm{CHX})$ can be used in endodontics as an irrigant and intracanal medicament due to its biocompatibility, substantivity and wide antimicrobial activity ${ }^{17,18}$. The antimicrobial property of $\mathrm{CHX}$ is attributed to its cationic molecule, which is adsorbed to the negatively charged inner cell membrane, resulting in the leakage of intracellular components. It is an effective agent against grampositive and gram-negative bacteria ${ }^{39}$. Importantly, it is effective against microorganisms resistant to $\mathrm{CH}^{90}$.

Enterococcus faecalis (E. faecalis) is a grampositive facultative anaerobic bacteria species. It is one of the most $\mathrm{CH}$-resistant microorganisms of the root canal system ${ }^{100}$. Although it comprises a small proportion of the root canal flora in initial endodontic infections, environmental changes can be advantageous to $E$. faecalis, resulting in persistent infections ${ }^{99}$. Some resistance factors of this bacterial species are deep dentinal penetration ability ${ }^{33}$, high $\mathrm{pH}$ tolerance ${ }^{19}$, surviving in food deprivation condition ${ }^{100}$, and surviving without any support from other microbial species $^{70}$.

Many studies have attempted to compare antibacterial effect of $\mathrm{CH}$ alone or in combination with $\mathrm{CHX}$. Some studies have shown an increased

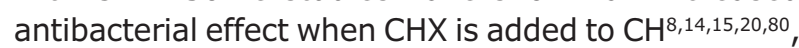
while other studies have failed to show any benefits

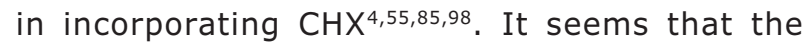
usefulness of mixing $\mathrm{CH}$ with $\mathrm{CHX}$ remains unclear and controversial ${ }^{61}$. Therefore, the aim of this systematic review and meta-analysis was to determine whether adding $\mathrm{CHX}$ to $\mathrm{CH}$ can improve the efficacy of $\mathrm{CH}$ against $E$. faecalis in dentinal tubules or not.

\section{MATERIAL AND METHODS}

\section{Review question}

The following well-defined review question was developed by using the Population, Intervention, Comparison, and Outcome (PICO) framework: Does $\mathrm{CH} / \mathrm{CHX}$ mixture (I), compared to $\mathrm{CH}$ alone (C), result in higher antimicrobial efficacy $(O)$ against $E$. faecalis $(P)$ in infected dentin? Therefore, the key words for search strategy were "Enterococcus faecalis" and "E. faecalis" as Population, "chlorhexidine" as Intervention, "calcium hydroxide" as Comparison, and "antimicrobial" and "antibacterial" as Outcome.

\section{Search strategy}

A comprehensive search of the literature was performed in Medline (PubMed), EMbase, EBSCOhost, The Cochrane Library SciELO, and BBO databases from the earliest available date to February 1, 2013 by an expert researcher in health and medical sciences (HN). Also, unpublished data, abstracts, and gray literature were sought through clinical trials registries (Australian New Zealand Clinical Trials Registry, Brazilian Clinical Trials Registry, Iranian Registry of Clinical Trials, United States National Institutes of Health, ClinicalTrials.gov, World Health Organization International Clinical Trials Registry Platform, and European Union EU Clinical Trials Registry), Open Grey, and conference proceedings.

The key words were organized according to the PICO model and were ["Enterococcus faecalis" OR "E. faecalis"] AND chlorhexidine AND "calcium hydroxide" AND [antimicrobial OR antibacterial]. No limitations were implemented by country of origin, language or date. The identified studies were combined using the bibliographic software EndNote X4 (Thomson Reuters, Carlsbad, CA, USA).

\section{Study selection and data extraction}

Two independent reviewers (MS, AS) screened the titles and abstracts of all the identified studies to determine relevant studies which met predetermined inclusion criteria. If there were insufficient data to make a clear decision, the full text was considered. Backward and forward searches from the relevant studies were also conducted, and the references of relevant studies were checked as backward search. Also, a forward search was undertaken on the titles of the relevant studies. Articles that had cited these studies were also identified through http://www. scholar.google.com to identify potentially relevant subsequent primary research.

These two independent reviewers assessed the full texts of relevant studies based on inclusion and exclusion criteria, which were proposed by three professionals related to each part of the study: two endodontists (MS, AS), an epidemiologist (MM), and a microbiologist (HS).

Inclusion criteria were as follows:

In vivo or ex vivo study using dentin block model microbiological assessment

Human or bovine dentin

$\mathrm{CH}$ in combination with $\mathrm{CHX}$ in the $\mathrm{CH} / \mathrm{CHX}$ group

$\mathrm{CH}$ in combination with distilled water or saline in the $\mathrm{CH}$-alone group

E. faecalis as a strain for microbiological assessment

Dressing period of at least 1 day

Quantitative results provided

Exclusion criteria were as follows:

Review article

In vitro study 
Vehicles other than distilled water or saline for $\mathrm{CH}$-alone group

$\mathrm{CH}$ or $\mathrm{CHX}$ as medicament in other materials

Any intervention except medicament dressing for bacterial elimination

Qualitative results or invalid means and standard deviations (SD) reported

Any disagreements on study inclusion and exclusion criteria were discussed and resolved by consulting a third reviewer.

\section{Data extraction, synthesis and analysis}

The included studies were reviewed and divided into "comparisons" according to dressing periods and depths of sampling. Sample size, microbiologic unit, depth of sampling, type and concentration of $\mathrm{CHX}$, significance, and means (SD) were recorded for each comparison individually. A microbiological unit for two included studies ${ }^{8,98}$ was optical density (OD) and for other included studies it was the colony forming unit (CFU). In order to identify the measurement scale, the results of these two studies were transformed from $O D$ to CFU according to microbiological equation (OD of 0.5 corresponding to $\left.\sim 5 \times 10^{8} \mathrm{CFU} / \mathrm{mL}\right)^{36}$. The results of six included studies $4,8,15,20,55,98$ were converted to the logarithm of CFU in order to achieve identical data for meta-analysis. Since SD had not been reported in some studies ${ }^{15,55,98}$, it was estimated and used for further analysis by using formula of t-test and application of means, sample size, and $p$ value of each study.

Statistical analysis was performed using Stata software version 10.0 for Windows (Stata Corp LP, College Station, Texas, USA). The level of significance was set at 0.05 . After checking the heterogeneity of comparisons using Chi-square analysis, Randomeffect meta-analysis model was used to estimate the combined effect. The results of these comparisons were represented by Forest plot. The potential risk of publication bias was evaluated using Begg's and Egger's tests.

Although the antibacterial effect of medicaments was evaluated with different depths of sampling ranges (from $0.05 \mathrm{~mm}$ to $0.45 \mathrm{~mm}$ ) in the included studies, subgroup analysis was performed based on the depth of sampling. Therefore, the comparisons were divided into surface (depth of sampling $\leq 0.2$ $\mathrm{mm}$ ) and deep (depth of sampling $>0.2 \mathrm{~mm}$ ) dentin groups.

\section{RESULTS}

The results of the search strategy are presented in Figure 1. Figure 2 presents a flow chart of the systematic review process. The final results of the search in Medline (via PubMed), EMbase, EBSCOhost, The Cochrane Library, SciELO, and BBO were 77, 65, 17, 3, 4, and 7 studies, respectively. After the primary review,

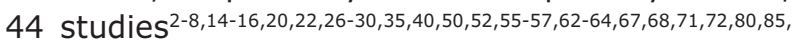
$89,95,97,98,102,104,105,107,113-115$ were considered relevant,

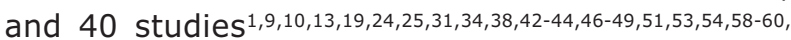
$65,66,69,75-79,81,83,86,94,103,106,110-112$ were irrelevant. Interobserver agreement (Cohen kappa) was 0.93. One additional study ${ }^{82}$ was considered relevant by backward and forward search. Thus, 45 studies were considered as irrelevant ( 5 in vivo, 18 in vitro, 18 ex vivo, and 4 review articles). By implementation of inclusion and exclusion criteria, nine studies $4,8,14,15,20,55,80,85,98$ were included and 36 studies $2,3,5-7,16,22,26-30,35,40,50,52,56,57,62-64,67,68,71,72,82,89,95,97$, 102,104,105,107,113-115 were excluded (Figure 3).

Twenty-one comparisons from the nine included studies were extracted (Table 1). Eight comparisons showed no significant differences in antibacterial effects between $\mathrm{CH}$ and $\mathrm{CH} / \mathrm{CHX}$ mixture; ten comparisons showed significant differences in favor of $\mathrm{CH} / \mathrm{CHX}$ mixture; and 3 comparisons showed significant differences in favor of $\mathrm{CH}$ alone against $E$. faecalis. The 21 comparisons were heterogeneous (Cochran Q Test of Homogeneity $(x 2)=144.22$, $\mathrm{df}=20, \mathrm{p}<0.001)$. Therefore, random effect method for combining comparison estimates was used and an overall estimate was produced. There were no significant differences in antibacterial effects between $\mathrm{CH} / \mathrm{CHX}$ mixture and $\mathrm{CH}$ alone against $E$. faecalis $(p=0.115)$ (Figure 4A).

The estimated ranks of correlation coefficients of Begg's and Egger's tests were $0.21(p=0.809)$ and $0.23(p=0.215)$, respectively, which means that there is no evidence for considerable publication bias in this study (Figure 4B).

In addition, subgroup analysis showed no

\begin{tabular}{|c|c|c|c|c|c|c|}
\hline Entry & \multicolumn{6}{|c|}{ Results } \\
\hline & PubMed & EMbase & EBSCO & Chochrane & SciELO & BBO \\
\hline $\begin{array}{c}\text { \#1: "Enterococcus faecalis" OR } \\
\text { "E. faecalis" }\end{array}$ & 11298 & 18879 & 2938 & 194 & 218 & 197 \\
\hline \#2: Chlorhexidine & 7664 & 14568 & 2167 & 2222 & 192 & 438 \\
\hline \#3: "Calcium hydroxide" & 4259 & 4599 & 1540 & 296 & 163 & 703 \\
\hline \#4: antibacterial OR antimicrobial & 1286445 & 2250318 & 80454 & 7143 & 2775 & 447 \\
\hline \#5: \#1 AND \#2 AND \#3 AND \#4 & 77 & 65 & 17 & 3 & 4 & 7 \\
\hline
\end{tabular}

Figure 1- Search strategy through PubMed, EMbase, EBSCOhost, The Cochrane Library, SciELO, and BBO 
Studies retrieved from PubMed, EMbase, EBSCOhost, The Cochrane Library, SciELO, and BBO databases $(n=77,65,17,3,4, \& 7$, respectively)

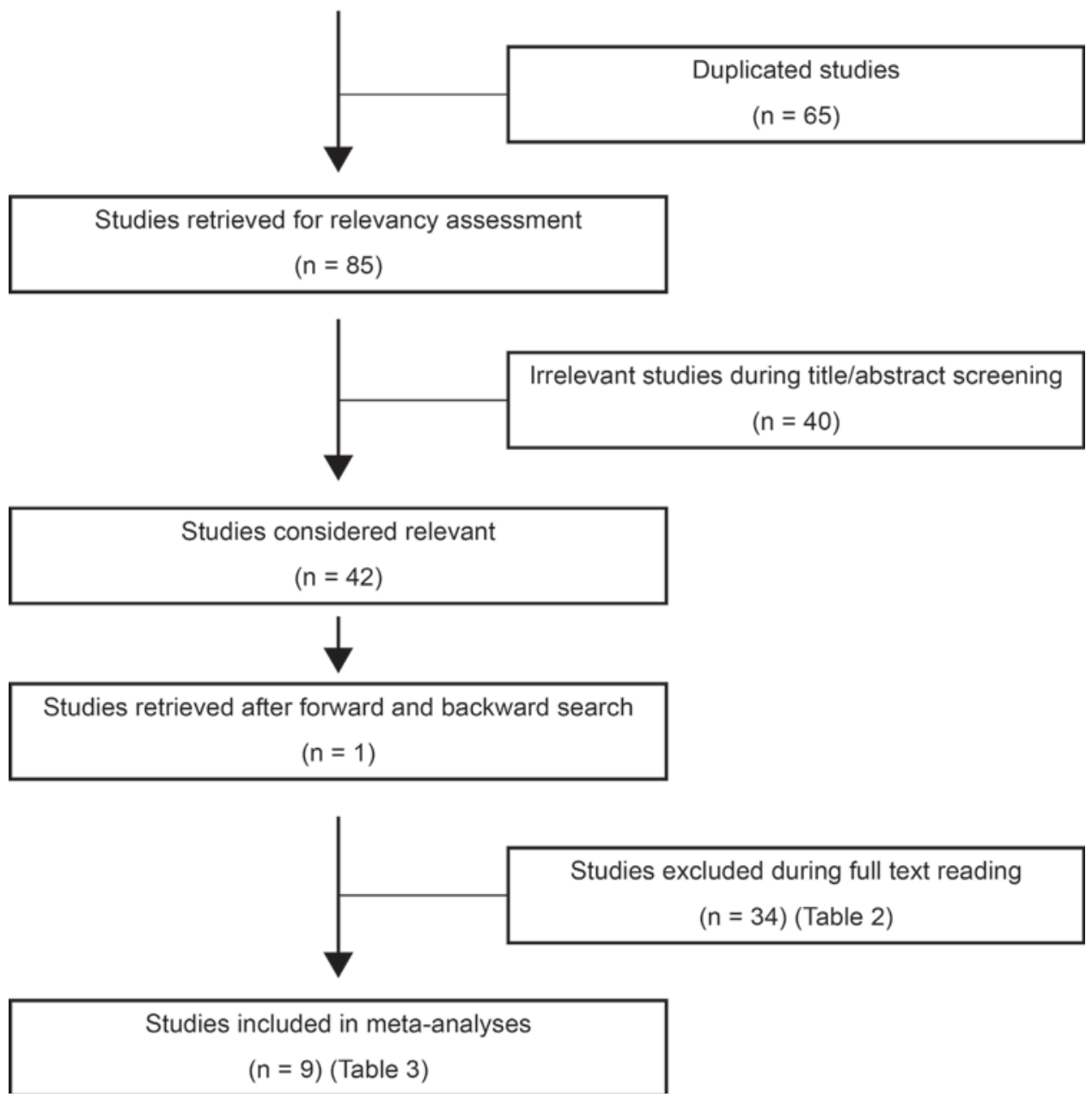

Figure 2- Flow chart of the search strategy

significant differences in antibacterial effects between $\mathrm{CH} / \mathrm{CHX}$ mixture and $\mathrm{CH}$ alone against $E$. faecalis in the surface $(p=0.11)$ and deep $(p=0.57)$ dentin (Figures 5A and 5B).

\section{DISCUSSION}

The benefit of mixing $\mathrm{CH}$ with $\mathrm{CHX}$ to improve the antibacterial property of $\mathrm{CH}$ as an intracanal medicament in elimination of $E$. faecalis remains a matter of controversy. The possible reasons for this controversy are the differences in the methods and materials used, including microbiological assessments (i.e. agar diffusion method, dentin block model etc.), concentrations and physical forms of $\mathrm{CHX}$ (i.e. gel, solution), time periods of experiments, strains and concentrations of $E$. faecalis, methods of bacterial inoculation, methods used for placing the medicaments, and depths of sampling.

Various methods have been used in order to define the antimicrobial effects of intracanal medicaments, such as dentin powder model, dentin block model, agar diffusion method, and broth dilution method. Agar diffusion is an in vitro model which has been the most commonly used technique ${ }^{91}$. However, it has some critical disadvantages, including "carryover" effect, unknown reactions between agar plate ingredients and the antimicrobial agent, absence of a true correlation between the results of agar diffusion method and the in vivo environment, the buffering capacity of the agar plate compromising the capacity of antimicrobial agent, and absence of differentiation between bactericidal and bacteriostatic agents ${ }^{33,91}$. Therefore, agar diffusion method was considered as an exclusion criterion. Dentin powder is an ex vivo model that has also some disadvantages, including partial loss of microanatomical structure of the tooth and the difficulty to create microbial biofilm ${ }^{33}$, therefore, it was also set as an exclusion criterion. Dentin block model, another ex vivo model, is the most standard method, and a statistical comparison is somehow feasible ${ }^{34}$. Penetration into dentinal tubules is the most important resistance mechanism of $E$. faecalis against antibacterial agents in endodontic 


\begin{tabular}{|c|c|}
\hline Studies & Exclusion criteria \\
\hline Estrela, et al..$^{16}(2001)$ & $2 \& 6$ \\
\hline Basrani, et al. ${ }^{7}$ (2002) & 5 \\
\hline Gomes, et al. ${ }^{27}(2003)$ & 3 \\
\hline Haenni, et al. ${ }^{35}(2003)$ & 2 \\
\hline Lin, et al..$^{52}(2003)$ & 2 \\
\hline Zehnder, et al. ${ }^{114}$ (2003) & 6 \\
\hline Siren, et al..$^{95}(2004)$ & 6 \\
\hline Zerella, et al. ${ }^{115}(2005)$ & 5 \\
\hline Onçag, et al. ${ }^{68}$ (2006) & 2 \\
\hline Oztan, et al. ${ }^{71}(2006)$ & $2 \& 3 \& 4$ \\
\hline Gomes, et al. ${ }^{28}(2006)$ & 2 \\
\hline Ballal, et al. ${ }^{6}(2007)$ & 2 \\
\hline $\begin{array}{l}\begin{array}{l}\text { Wang Kou; Siguas Meneses } \\
(2007)\end{array} \\
\end{array}$ & $4 \& 5$ \\
\hline Souza-Filho, et al. ${ }^{97}(2008)$ & 2 \\
\hline Vianna, et al. ${ }^{109}(2008)$ & $2 \& 5$ \\
\hline Gomes, et al. ${ }^{26}(2009)$ & 2 \\
\hline Ravishanker; Rao ${ }^{82}$ (2009) & 2 \\
\hline Aguiar $^{3}$ (2009) & 5 \\
\hline Turk, et al. ${ }^{102}$ (2009) & 2 \\
\hline Valera, et al. ${ }^{105}$ (2009) & 5 \\
\hline Jhamb, et al. ${ }^{40}(2010)$ & 2 \\
\hline Mohammadi62 (2010) $^{2}$ & 1 \\
\hline $\operatorname{Gondim}^{29}(2010)$ & $3 \& 5$ \\
\hline Oliveira, et al.$^{67}(2010)$ & $2 \& 3$ \\
\hline Maekawa $^{56}(2010)$ & 5 \\
\hline Valera, et al. ${ }^{104}(2010)$ & 5 \\
\hline Mohammadi; Dummer ${ }^{63}$ (2011) & 1 \\
\hline Silveira, et al ${ }^{89}(2011)$ & 2 \\
\hline Gondim, et al..$^{30}(2012)$ & $2 \& 3$ \\
\hline Lima, et al..$^{50}(2012)$ & 3 \\
\hline Fedorowicz, et al. ${ }^{22}$ (2012) & 1 \\
\hline Maekawa, et al. ${ }^{57}(2013)$ & 5 \\
\hline Pacios, et al. ${ }^{72}$ (2012) & 2 \\
\hline Adl, et al. ${ }^{2}$ (2012) & 2 \\
\hline Mohammadi; Shalavi ${ }^{64}$ (2012) & 1 \\
\hline Atila-Pektaş, et al. ${ }^{5}$ (2013) & 4 \\
\hline
\end{tabular}

$1=$ Review article, $2=$ In vitro study, $3=$ Vehicles other than distilled water or saline for $\mathrm{CH}$-alone group, $4=\mathrm{CH}$ or $\mathrm{CHX}$ as medicament in other materials, 5=Any intervention except medicament dressing for bacterial elimination, $6=$ Qualitative results or invalid means and standard deviations $(S D)$ reported

Figure 3- Excluded studies with reasons for exclusion treatment ${ }^{32,92}$. This model provides reconstruction of the microanatomy of dentin, especially dentinal tubules. Dentin block model also simulates the chemical environment of the root canal and the ability of biofilm development ${ }^{33}$, therefore, it was set as an inclusion criterion.

In general, three types of vehicles are used for preparing $\mathrm{CH}$ : aqueous, viscous, and $\mathrm{oil}^{21}$. The first group promotes a high degree of solubility when the paste remains in direct contact with tissues and tissue fluids ${ }^{21}$. The two other types result in the lower solubility and diffusion of the paste within the tissues ${ }^{21}$. In addition, some aqueous vehicles such as camphorated monochlorophenol have antibacterial effect on microorganisms, therefore, vehicles other than distilled water or saline solution for $\mathrm{CH}$-alone group was set as exclusion criteria.

Since the evaluation of antibacterial effect of $\mathrm{CH}$ as an intracanal dressing was the aim of this meta-analysis, the use of antimicrobial irrigants in addition to the $\mathrm{CH}$ intracanal medication were considered confounding factors. Some relevant articles have presented this confounding factor as chemomechanical preparation of the canal before $\mathrm{CH}$ dressing and after microbial suspension inoculation into the canal $3,29,56,57,104,105,108,113,115$. In addition, one study has applied chemomechanical preparation after $\mathrm{CH}_{\text {dressing }}{ }^{7}$, leading to the exclusion of these studies.

The time needed for $\mathrm{CH}$ to optimally disinfect the root canal system is still unknown and might be related to root canal exudate, the microorganism type, microorganism location in the root canal system, the smear layer, and the degree of susceptibility to the medication ${ }^{28}$. Although Shuping, et al. ${ }^{88}$ (2000) reported that use of $\mathrm{CH}$ in the canals for 1 week resulted in a $92.5 \%$ reduction, evidence shows that $\mathrm{CHX}$ has antibacterial activity against $E$. faecalis after 1 day 27,34,45. In addition, two studies showed that $\mathrm{CH}$ can be effective against enterococci after 24 hours $^{84,96}$. Therefore, at least one day of dressing period was set as an inclusion criterion. Furthermore, the main dentinal structure of human and bovine teeth is not significantly different ${ }^{32}$. Therefore, the results of studies using both of them were used in the meta-analysis.

Evans, et al. ${ }^{20}$ (2003) evaluated the antibacterial effect of $\mathrm{CH} / \mathrm{CHX}$ mixture with two different depths of sampling, but they reported one mean and SD. Therefore, this study was considered as one comparison and was included in the meta-analysis. Another included study ${ }^{4}$ was divided into nine comparisons according to different dressing periods and depths of sampling, but seven comparisons were excluded because of invalid means and standard deviations.

Qualitative data are not suitable for metaanalysis. Despite meeting all the inclusion criteria, 
Table 1- Comparisons within 9 included studies

\begin{tabular}{|c|c|c|c|c|c|c|c|c|}
\hline \multirow[t]{2}{*}{ Reference } & \multirow{2}{*}{$\begin{array}{l}\text { Sample } \\
\text { size }\end{array}$} & \multirow{2}{*}{$\begin{array}{c}\text { Microbiologic } \\
\text { unit }\end{array}$} & \multirow{2}{*}{$\begin{array}{l}\text { Depth } \\
(\mathrm{mm})\end{array}$} & \multirow{2}{*}{$\begin{array}{c}\text { Dressing } \\
\text { period } \\
\text { (day) }\end{array}$} & \multirow[t]{2}{*}{ Sig. } & \multirow{2}{*}{$\begin{array}{l}\text { CHX type \& } \\
\text { concentration }\end{array}$} & \multicolumn{2}{|c|}{ Mean (SD) } \\
\hline & & & & & & & $\mathrm{CH}$ & $\mathrm{CH} / \mathrm{CHX}$ \\
\hline $\begin{array}{l}\text { Almyroudi, et al. }{ }^{4} \\
(2002)\end{array}$ & 16 & CFU & 0.1 & 14 & 0 & $1 \%$ Gel & $2.70(2.90)$ & $0.70(0.97)$ \\
\hline $\begin{array}{l}\text { Almyroudi, et al. }{ }^{4} \\
\qquad(2002)\end{array}$ & 16 & CFU & 0.35 & 14 & 0 & $1 \% \mathrm{Gel}$ & $1.57(1.85)$ & $0.40(0.85)$ \\
\hline $\begin{array}{l}\text { Sukawat; Srisuwan }{ }^{98} \\
(2002)\end{array}$ & 12 & OD & 0.2 & 7 & 0 & $0.2 \%$ Sol & $9.44\left(0.76^{*}\right)$ & $9.43\left(0.76^{*}\right)$ \\
\hline $\begin{array}{c}\text { Sukawat; Srisuwan }{ }^{98} \\
(2002)\end{array}$ & 12 & OD & 0.35 & 7 & 0 & $0.2 \%$ Sol & $9.70\left(3.80^{\star}\right)$ & $9.75\left(3.80^{*}\right)$ \\
\hline Basrani, et al. ${ }^{8}(2003)$ & 30 & OD & 0.1 & 7 & 1 & $0.2 \% \mathrm{Gel}$ & $8.76\left(7.78^{*}\right)$ & $7.90\left(7.60^{*}\right)$ \\
\hline Basrani, et al. ${ }^{8}(2003)$ & 30 & OD & 0.2 & 7 & 1 & $0.2 \% \mathrm{Gel}$ & $8.83\left(7.60^{*}\right)$ & $7.95\left(7.48^{*}\right)$ \\
\hline Evans, et al. ${ }^{20}(2003)$ & 24 & CFU & 0.45 & 7 & 1 & $2 \%$ Sol & $3.02(1.50)$ & $1.36(1.61)$ \\
\hline Lynne, et al. ${ }^{55}$ (2003) & 12 & CFU & 0.29 & 1 & 2 & $0.12 \%$ Sol & $5.25\left(0.35^{\star}\right)$ & $5.75\left(0.35^{\star}\right)$ \\
\hline Lynne, et al. ${ }^{55}$ (2003) & 12 & CFU & 0.35 & 1 & 2 & $0.12 \%$ Sol & $5.17\left(0.26^{*}\right)$ & $5.54\left(0.26^{*}\right)$ \\
\hline Lynne, et al. ${ }^{55}$ (2003) & 12 & CFU & 0.42 & 1 & 2 & $0.12 \%$ Sol & $5.20\left(0.31^{*}\right)$ & $5.64\left(0.31^{*}\right)$ \\
\hline $\begin{array}{l}\text { Schäfer; Bossmann }{ }^{85} \\
\text { (2005) }\end{array}$ & 10 & CFU & 0.05 & 3 & 0 & $2 \%$ Sol & $2.14(0.26)$ & $2.57(0.04)$ \\
\hline $\begin{array}{l}\text { Schäfer; Bossmann }{ }^{85} \\
(2005)\end{array}$ & 10 & CFU & 0.1 & 3 & 0 & $2 \%$ Sol & $1.85(0.41)$ & $1.93(0.16)$ \\
\hline $\begin{array}{l}\text { Schäfer; Bossmann }{ }^{85} \\
\text { (2005) }\end{array}$ & 10 & CFU & 0.15 & 3 & 0 & $2 \%$ Sol & $1.43(0.18)$ & $1.52(0.08)$ \\
\hline $\begin{array}{l}\text { Schäfer; Bossmann }{ }^{85} \\
(2005)\end{array}$ & 10 & CFU & 0.2 & 3 & 0 & $2 \%$ Sol & $1.06(0.31)$ & $1.36(0.14)$ \\
\hline Ercan, et al. ${ }^{15}(2006)$ & 12 & CFU & 0.4 & 7 & 1 & $2 \%$ Sol & $7.90\left(0.42^{*}\right)$ & $7.30\left(0.42^{*}\right)$ \\
\hline Ercan, et al. ${ }^{15}(2006)$ & 12 & CFU & 0.4 & 15 & 1 & $2 \%$ Sol & $7.90\left(0.63^{*}\right)$ & $7.00\left(0.63^{*}\right)$ \\
\hline Ercan, et al. ${ }^{15}(2006)$ & 12 & CFU & 0.4 & 30 & 1 & $2 \%$ Sol & $7.90\left(0.63^{\star}\right)$ & $7.00\left(0.63^{*}\right)$ \\
\hline $\begin{array}{l}\text { Delgado, et al. }{ }^{14} \\
\qquad(2010)\end{array}$ & 30 & CFU & 0.1 & 14 & 1 & $2 \%$ Gel & $4.01(0.42)$ & $0.50(0.35)$ \\
\hline $\begin{array}{l}\text { Delgado, et al. }{ }^{14} \\
(2010)\end{array}$ & 30 & CFU & 0.2 & 14 & 1 & $2 \% \mathrm{Gel}$ & $3.69(0.47)$ & $0.77(0.44)$ \\
\hline $\begin{array}{l}\text { Perabhakal, et al. }{ }^{80} \\
\qquad(2012)\end{array}$ & 20 & CFU & 0.16 & 1 & 1 & $0.5 \%$ Sol & $2.40(1.68)$ & $2.05(1.35)$ \\
\hline $\begin{array}{l}\text { Perabhakal, et al. }{ }^{80} \\
\text { (2012) }\end{array}$ & 20 & CFU & 0.16 & 7 & 1 & $0.5 \%$ Sol & $2.28(1.62)$ & $1.87(1.16)$ \\
\hline
\end{tabular}

Sig.=Significance, $\mathrm{CHX}=$ Chlorhexidine, $\mathrm{CH}=$ Calcium Hydroxide, Sol=Solution, $\mathrm{CFU}=$ Colony Forming Unit, OD=Optical Density, ${ }^{*}=$ estimated standard deviation, Sig. $0=$ no significant difference between $\mathrm{CH}$ and $\mathrm{CH} / \mathrm{CHX}$, Sig. $1=$ in favor of $\mathrm{CH} /$ $\mathrm{CHX}$, Sig. $2=$ in favor of $\mathrm{CH}$. SD= standard deviation.

two relevant studies ${ }^{95,114}$ were excluded because they did not provide quantitative data. The results of four included studies $8,14,55,98$ were illustrated in charts. Therefore, quantitative data were extracted from the illustrated charts using Adobe Photoshop software 5.0 (Adobe Systems, Mountain View, CA, USA) for Windows. To achieve more reliable data, a $300 \%$ zoom was used.
The greatest difference in the antibacterial activity of $\mathrm{CH} / \mathrm{CHX}$ and $\mathrm{CH}$ groups has been reported in the study performed by Delgado, et al. ${ }^{14}$ (2010). This might be due to longer dressing period, sample size, type and concentration of $\mathrm{CHX}$ compared with other studies.

In the present study, Cochran $Q$ Test of Homogeneity showed that the 21 comparisons were 

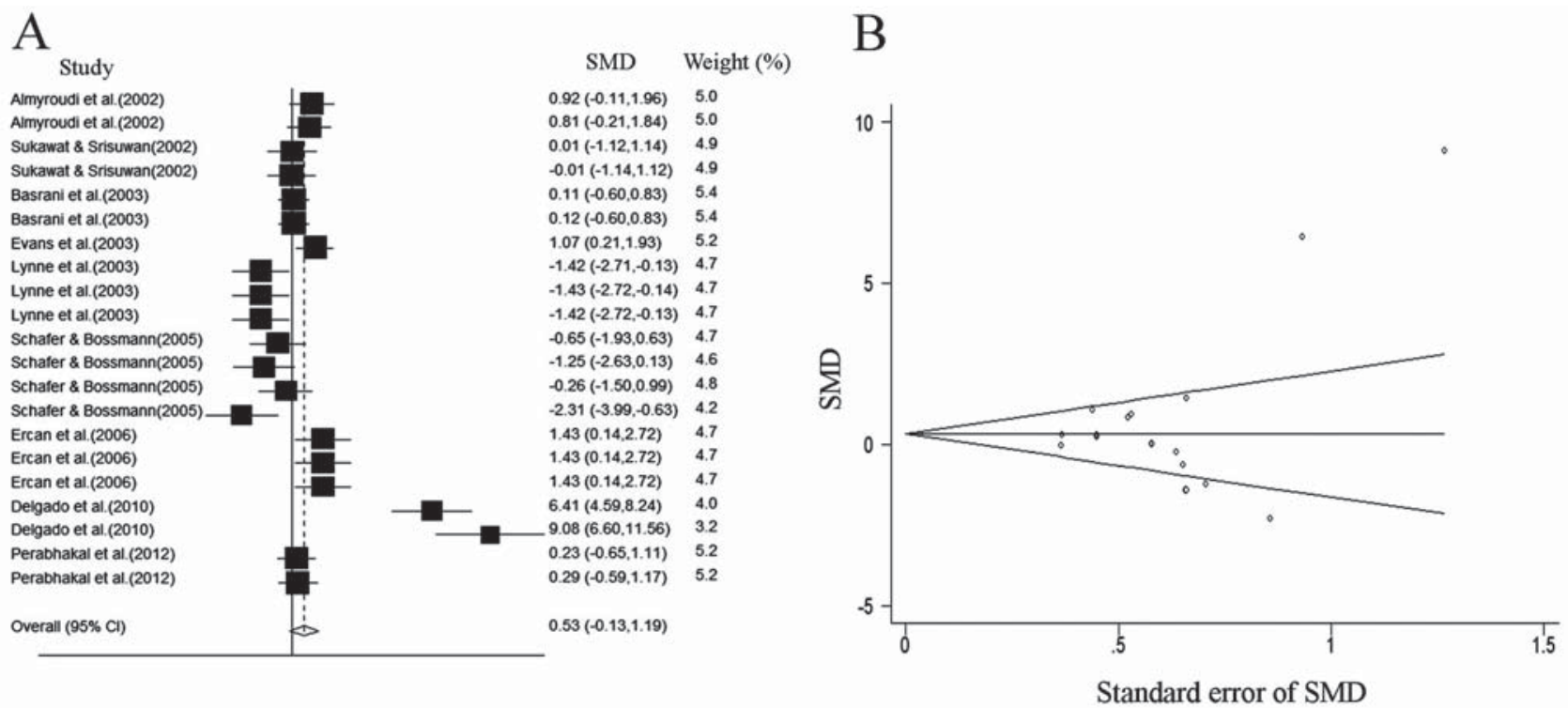

Figure 4-A: Forest plot for antibacterial effect of medicaments on E. faecalis. The box, its size and the horizontal line show the point of estimation, statistical weight and $95 \%$ confidence interval of each comparison, respectively. The diamond at the bottom of the figure illustrates the combined effect on the random effect model; B: Begg's Funnel Plot with 95\% confidence limit for antibacterial effect of medicaments on E. faecalis. The plot shows a low risk of publication bias among the included articles. SMD: Standardized Mean Differentiation
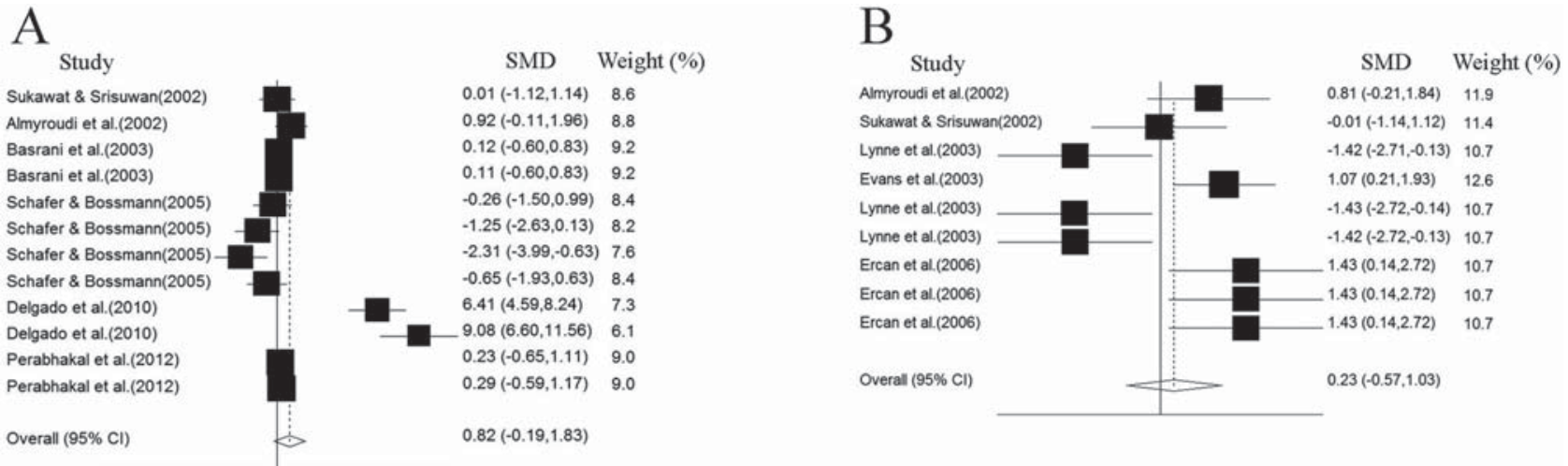

Figure 5- A and B: Forest plots for antibacterial effect of medicaments against $E$. faecalis in surface and deep dentin respectively. SMD: Standardized Mean Differentiation

heterogeneous. This might be due to differences in subjects (human or bovine dentin), method of medicament placement, dressing period, depth of sampling, and type and concentration of $\mathrm{CHX}$.

Meta-analysis is a research tool designed to analyze and combine the inconsistent results of controversial subjects, particularly with those of randomized clinical trials. However, this method has been applied to in vitro studies $23,73,87,107$. Since there were no clinical trials on the subject of this systematic review, in vitro studies had to be selected. Therefore, only ex vivo dentin block model studies were selected, which have the greatest similarity to clinical conditions. This model, in comparison to other microbiological assessment models, is of high methodological quality and can simulate the clinical situation in the best way possible. On the other hand, the effectiveness of the medicament in vivo can be reduced by a variety of factors. These include problems in delivery, low overall volume, poor/incomplete penetration in the main root canal system, poor penetration into dentin, short contact time, or inactivation of the activity of the antibacterial agent by one or more of the chemical compounds present in the necrotic root canal.

The results of the present meta-analysis showed that $\mathrm{CHX}$ does not increase the antibacterial effect of $\mathrm{CH}$. This may be due to deprotonation of $\mathrm{CHX}$ at high $\mathrm{pH}$, which reduces its solubility and alters its interaction with bacterial surfaces as a result of the altered charge of the molecule ${ }^{64}$.

In conclusion it appears that mixing $\mathrm{CH}$ with $\mathrm{CHX}$ does not improve its ex vivo antibacterial property as an intracanal medicament against $E$. faecalis. Further in vivo studies are necessary to confirm and correlate the findings of this study with the clinical outcomes. 


\section{ACKNOWLEDGMENTS}

This study was supported by Isfahan University of Medical Sciences, Iran (grant no. 291230). The authors declare no conflict of interests.

\section{REFERENCES}

1- Abdullah M, Ng YL, Gulabivala K, Moles DR, Spratt DA. Susceptibilties of two Enterococcus faecalis phenotypes to root canal medications. J Endod. 2005;31:30-6.

2- Adl A, Shojaee NS, Motamedifar M. A comparison between the antimicrobial effects of triple antibiotic paste and calcium hydroxide against Enterococcus faecalis. Iran Endod J. 2012;7:149-55.

3- Aguiar APS. Ação in vitro do extrato glicólico de gengibre e medicamentos sobre Candida albicans, Enterococcus faecalis, Escherichia coli e sua endotoxina em canais radiculares [Masters Degree]. São José dos Campos: Univ. Estadual Paulista - UNESP; 2009. Available from: http://www.athena.biblioteca.unesp.br/ exlibris/bd/bsj/33004145070P8/2009/aguiar_aps_me_sjc.pdf. 4- Almyroudi A, Mackenzie D, McHugh S, Saunders WP. The effectiveness of various disinfectants used as endodontic intracanal medications: an in vitro study. J Endod. 2002;28:163-7.

5- Atila-Pektaş B, Yurdakul P, Gülmez D, Görduysus O. Antimicrobial effects of root canal medicaments against Enterococcus faecalis and Streptococcus mutans. Int Endod J. 2013;46:413-8.

6- Ballal V, Kundabala M, Acharya S, Ballal M. Antimicrobial action of calcium hydroxide, chlorhexidine and their combination on endodontic pathogens. Aust Dent J. 2007;52:118-21.

7- Basrani B, Santos JM, Tjäderhane L, Grad H, Gorduysus O, Huang J, et al. Substantive antimicrobial activity in chlorhexidine-treated human root dentin. Oral Surg Oral Med Oral Pathol Oral Radiol Endod. 2002;94:240-5.

8- Basrani B, Tjäderhane L, Santos JM, Pascon E, Grad H, Lawrence $\mathrm{HP}$, et al. Efficacy of chlorhexidine- and calcium hydroxide-containing medicaments against Enterococcus faecalis in vitro. Oral Surg Oral Med Oral Pathol Oral Radiol Endod. 2003;96:618-24.

9- Bhardwaj A, Ballal S, Velmurugan N. Comparative evaluation of the antimicrobial activity of natural extracts of Morinda citrifolia, papain and aloe vera (all in gel formulation), $2 \%$ chlorhexidine gel and calcium hydroxide, against Enterococcus faecalis: an in vitro study. J Conserv Dent. 2012;15:293-7.

10- Bozza FL, Molgatini SL, Pérez SB, Tejerina DP, Pérez Tito RI, Kaplan AE. Antimicrobial effect in vitro of chlorhexidine and calcium hydroxide impregnated gutta-percha points. Acta Odontol Latinoam. 2005;18:51-6.

11- Byström A, Claesson R, Sundqvist G. The antibacterial effect of camphorated paramonochlorophenol, camphorated phenol and calcium hydroxide in the treatment of infected root canals. Dent Traumatol. $1985 ; 1: 170-5$.

12- Byström A, Sundqvist G. Bacteriologic evaluation of the efficacy of mechanical root canal instrumentation in endodontic therapy. Scand J Dent Res. 1981;89:321-8.

13- Cook J, Nandakumar R, Fouad AF. Molecular- and culture-based comparison of the effects of antimicrobial agents on bacterial survival in infected dentinal tubules. J Endod. 2007;33:690-2.

14- Delgado RJ, Gasparoto TH, Sipert CR, Pinheiro CR, Moraes IG, Garcia RB, et al. Antimicrobial effects of calcium hydroxide and chlorhexidine on Enterococcus faecalis. J Endod. 2010;36:1389-93. 15- Ercan E, Dalli M, Dülgergil CT. In vitro assessment of the effectiveness of chlorhexidine gel and calcium hydroxide paste with chlorhexidine against Enterococcus faecalis and Candida albicans. Oral Surg Oral Med Oral Pathol Oral Radiol Endod. 2006;102:e27-31. 16- Estrela C, Bammann LL, Pimenta FC, Pécora JD. Control of microorganisms in vitro by calcium hydroxide pastes. Int Endod J. 2001;34:341-5.
17- Estrela CR, Estrela C, Reis C, Bammann LL, Pécora JD. Control of microorganisms in vitro by endodontic irrigants. Braz Dent J. 2003; 14:187-92.

18- Evanov C, Liewehr F, Buxton TB, Joyce AP. Antibacterial efficacy of calcium hydroxide and chlorhexidine gluconate irrigants at 37 degrees C and 46 degrees C. J Endod. 2004;30:653-7.

19- Evans M, Davies J, Sundqvist G, Figdor D. Mechanisms involved in the resistance of Enterococcus faecalis to calcium hydroxide. Int Endod J. 2002;35:221-8.

20- Evans MD, Baumgartner JC, Khemaleelakul SU, Xia T. Efficacy of calcium hydroxide: chlorhexidine paste as an intracanal medication in bovine dentin. J Endod. 2003;29:338-9.

21- Fava LR, Saunders WP. Calcium hydroxide pastes: classification and clinical indications. Int Endod J. 1999:32:257-82.

22- Fedorowicz Z, Nasser M, Sequeira-Byron P, Souza RF, Carter B, Heft M. Irrigants for non-surgical root canal treatment in mature permanent teeth. Cochrane Database Syst Rev 2012;9:CD008948. 23- Finnema KJ, Özcan M, Post WJ, Ren $Y$, Dijkstra PU. In-vitro orthodontic bond strength testing: a systematic review and metaanalysis. Am J Orthod Dentofac Orthop. 2010;137:615-22. e3.

24- Fouad AF, Barry J. The effect of antibiotics and endodontic antimicrobials on the polymerase chain reaction. J Endod. 2005;31:510-3.

25- Gomes BP, Ferraz CC, Garrido FD, Rosalen PL, Zaia AA, Teixeira $\mathrm{FB}$, et al. Microbial susceptibility to calcium hydroxide pastes and their vehicles. J Endod. 2002;28:758-61.

26- Gomes BP, Montagner F, Berber VB, Zaia AA, Ferraz CC, Almeida $\mathrm{JF}$, et al. Antimicrobial action of intracanal medicaments on the external root surface. J Dent. 2009;37:76-81.

27- Gomes BP, Souza SF, Ferraz CC, Teixeira FB, Zaia AA, Valdrighi $L$, et al. Effectiveness of $2 \%$ chlorhexidine gel and calcium hydroxide against Enterococcus faecalis in bovine root dentine in vitro. Int Endod J. 2003;36:267-75.

28- Gomes BP, Vianna ME, Sena NT, Zaia AA, Ferraz CC, Souza Filho FJ. In vitro evaluation of the antimicrobial activity of calcium hydroxide combined with chlorhexidine gel used as intracanal medicament. Oral Surg Oral Med Oral Pathol Oral Radiol Endod. 2006;102:544-50.

29- Gondim JO. Efeito antibacteriano e sucesso clínico/radiográfico da pasta de hidróxido de cálcio associada à clorexidina como medicação intracanal no tratamento de dentes decíduos humanos com polpa necrótica $[\mathrm{PhD}]$. Araraquara: Univ. Estadual Paulista UNESP; 2010. Available from: http://www.athena.biblioteca.unesp. br/exlibris/bd/boa/33004030010P2/2010/gondim_jo_dr_arafo.pdf. 30- Gondim JO, Avaca-Crusca JS, Valentini SR, Zanelli CF, Spolidorio DM, Giro EM. Effect of a calcium hydroxide/chlorhexidine paste as intracanal dressing in human primary teeth with necrotic pulp against Porphyromonas gingivalis and Enterococcus faecalis. Int J Paediatr Dent. 2012;22:116-24.

31- Gurgel-Filho ED, Vivacqua-Gomes N, Gomes BP, Ferraz CC, Zaia AA, Souza-Filho FJ. In vitro evaluation of the effectiveness of the chemomechanical preparation against Enterococcus faecalis after single- or multiple-visit root canal treatment. Braz Oral Res. 2007;21:308-13.

32- Haapasalo $M$, Ørstavik D. In vitro infection and of dentinal tubules. J Dent Res. 1987;66:1375-9.

33- Haapasalo M, Qian W. Irrigants and intracanal medicaments. In: Ingle JI, Bakland LK, Baumgartner JC, editors. Endodontics. 6th ed. Hamilton: BC Decker; 2008. p. 996.

34- Haapasalo H, Sirén E, Waltimo T, Ørstavik D, Haapasalo MP. Inactivation of local root canal medicaments by dentine: an in vitro study. Int Endod J. 2000;33:126-31.

35- Haenni S, Schmidlin PR, Mueller B, Sener B, Zehnder M. Chemical and antimicrobial properties of calcium hydroxide mixed with irrigating solutions. Int Endod J. 2003;36:100-5.

36- Heikens E, Bonten MJM, Willems RJ. Enterococcal surface protein Esp is important for biofilm formation of Enterococcus faecium E1162. J Bacteriol. 2007;189:8233-40.

37- Heithersay GS. Calcium hydroxide in the treatment of pulpless teeth with associated pathology. Int Endod J. 1975;8:74-93. 
38- Heling I, Steinberg D, Kenig S, Gavrilovich I, Sela M, Friedman $M$. Efficacy of a sustained release device containing chlorhexidine and $\mathrm{Ca}(\mathrm{OH})_{2}$ in preventing secondary infection of dentinal tubules. Int Endod J. 1992;25:20-4.

39- Jeansonne MJ, White RR. A comparison of $2.0 \%$ chlorhexidine gluconate and $5.25 \%$ sodium hypochlorite as antimicrobial endodontic irrigants. J Endod. 1994;20:276-8.

40- Jhamb S, Nikhil V, Singh V. An in vitro study of antibacterial effect of calcium hydroxide and chlorhexidine on Enterococcus faecalis. Indian J Dent Res. 2010;21:512-4.

41- Kakehashi S, Stanley HR, Fitzgerald RJ. The effects of surgical exposures of dental pulps in germ-free and conventional laboratory rats. Oral Surg Oral Med Oral Pathol. 1965;20:340-9.

42- Kandaswamy D, Venkateshbabu N, Gogulnath D, Kindo AJ. Dentinal tubule disinfection with $2 \%$ chlorhexidine gel, propolis, morinda citrifolia juice, $2 \%$ povidone iodine, and calcium hydroxide. Int Endod J. 2010;43:419-23.

43- Kayaoglu G, Erten H, Ørstavik D. Possible role of the adhesin ace and collagen adherence in conveying resistance to disinfectants on Enterococcus faecalis. Oral Microbiol Immunol. 2008;23:449-54. 44- Kayaoglu G, Ömürlü H, Akca G, Gürel M, Gencay Ö, Sorkun K, et al. Antibacterial activity of Propolis versus conventional endodontic disinfectants against Enterococcus faecalis in infected dentinal tubules. J Endod. 2011;37:376-81.

45- Komorowski R, Grad H, Yu Wu X, Friedman S. Antimicrobial substantivity of chlorhexidine-treated bovine root dentin. J Endod. 2000;26:315-7.

46- Krithikadatta J, Indira R, Dorothykalyani AL. Disinfection of dentinal tubules with $2 \%$ chlorhexidine, $2 \%$ metronidazole, bioactive glass when compared with calcium hydroxide as intracanal medicaments. J Endod. 2007;33:1473-6.

47- Lee JK, Park YJ, Kum KY, Han S, Chang SW, Kaufman B, et al. Antimicrobial efficacy of a human $\beta$-defensin- 3 peptide using an Enterococcus faecalis dentine infection model. Int Endod J. 2013;46:406-12.

48- Lee $\mathrm{Y}$, Han SH, Hong SH, Lee JK, Ji H, Kum KY. Antimicrobial efficacy of a polymeric chlorhexidine release device using in vitro model of Enterococcus faecalis dentinal tubule infection. J Endod. 2008;34:855-8.

49- Lenet BJ, Komorowski R, Wu XY, Huang J, Grad H, Lawrence HP, et al. Antimicrobial substantivity of bovine root dentin exposed to different chlorhexidine delivery vehicles. J Endod. 2000;26:652-5. 50- Lima RK, Guerreiro-Tanomaru JM, Faria-Júnior NB, TanomaruFilho M. Effectiveness of calcium hydroxide-based intracanal medicaments against Enterococcus faecalis. Int Endod J. 2012;45:311-6.

51- Lin S, Levin L, Weiss EI, Peled M, Fuss Z. In vitro antibacterial efficacy of a new chlorhexidine slow-release device. Quintessence Int. 2006;37:391-4.

52- Lin YH, Mickel AK, Chogle S. Effectiveness of selected materials against Enterococcus faecalis: part 3. The antibacterial effect of calcium hydroxide and chlorhexidine on Enterococcus faecalis. J Endod. 2003;29:565-6.

53- Lucena JM, Decker EM, Walter C, Boeira LS, Löst C, Weiger R. Antimicrobial effectiveness of intracanal medicaments on Enterococcus faecalis: chlorhexidine versus octenidine. Int Endod J. 2012;46:53-61.

54- Lui JN, Sae-Lim V, Song KP, Chen NN. In vitro antimicrobial effect of chlorhexidine-impregnated gutta percha points on Enterococcus faecalis. Int Endod J. 2004;37:105-13.

55- Lynne RE, Liewehr FR, West LA, Patton WR, Buxton TB, McPherson JC. In vitro antimicrobial activity of various medication preparations on E. faecalis in root canal dentin. J Endod. 2003;29:187-90.

56- Maekawa LE. Avaliação dos extratos de própolis e de gengibre como medicação intracanal sobre microrganismos e endotoxinas em canais radiculares [PhD]. São José dos Campos: Univ Estadual Paulista - UNESP; 2010. Available from: http://www.athena. biblioteca.unesp.br/exlibris/bd/bsj/33004145070P8/2010/ maekawa_le_dr_sjc.pdf.
57- Maekawa LE, Valera MC, Oliveira LD, Carvalho CAT, Camargo CH, Jorge AO. Effect of Zingiber officinale and propolis on microorganisms and endotoxins in root canals. J Appl Oral Sci. 2013;21:25-31. 58- Maia Filho EM, Maia CCR, Bastos ACSC, Novais TMG. In vitro antimicrobial effect of different endodontic materials and propolis on Enterococcus faecalis. RGO. 2008;56:21-5.

59- Mattigati S, Ratnakar P, Moturi S, Varma S, Rairam S. Antimicrobial effect of conventional root canal medicaments vs propolis against Enterococcus faecalis, Staphylococcus aureus and Candida albicans. J Contemp Dent Prac. 2012;13:305-9.

60- Menezes M, Valera M, Jorge A, Koga-Ito C, Camargo C, Mancini M. In vitro evaluation of the effectiveness of irrigants and intracanal medicaments on microorganisms within root canals. Int Endod J. 2004;37:311-9.

61- Metzger Z, Basrani B, Goodis H. Instruments, materials, and devices. In: Hargreaves KM, Cohen S, editors. Pathways of the pulp. $10^{\text {th }}$ ed. St. Louis: Mosby; 2011. p. 283-348.

62- Mohammadi Z. Chemomechanical strategies to manage endodontic infections. Dent Today. 2010;29:91-2, 4, 6 passim; quiz 9.

63- Mohammadi Z, Dummer PM. Properties and applications of calcium hydroxide in endodontics and dental traumatology. Int Endod J. 2011;44:697-730.

64- Mohammadi Z, Shalavi S. Is chlorhexidine an ideal vehicle for calcium hydroxide? A microbiologic review. Iran Endod J. 2012; 7:115-22.

65- Neelakantan P, Sanjeev K, Subbarao CV. Duration-dependent susceptibility of endodontic pathogens to calcium hydroxide and chlorhexidene gel used as intracanal medicament: an in vitro evaluation. Oral Surg Oral Med Oral Pathol Oral Radiol Endod. 2007;104:e138-41.

66- Noetzel J, Nonhoff J, Bitter K, Wagner J, Neumann K, Kielbassa AM. Efficacy of calcium hydroxide, Er:YAG laser or gaseous ozone against Enterococcus faecalis in root canals. Am J Dent. 2009;22:148.

67- Oliveira JC, Alves FR, Uzeda M, Rôças IN, Siqueira JF Jr. Influence of serum and necrotic soft tissue on the antimicrobial effects of intracanal medicaments. Braz Dent J. 2010;21:295-300.

68- Onçag O, Cogulu D, Uzel A. Efficacy of various intracanal medicaments against Enterococcus faecalis in primary teeth: an in vivo study. J Clin Pediatr Dent. 2006;30:233-7.

69- Onçag O, Cogulu D, Uzel A, Sorkun K. Efficacy of propolis as an intracanal medicament against Enterococcus faecalis. Gen Dent. 2006;54:319-22.

70- Ørstavik D, Haapasalo M. Disinfection by endodontic irrigants and dressings of experimentally infected dentinal tubules. Dent Traumatol. 1990;6:142-9.

71- Oztan MD, Kiyan M, Gerçeker D. Antimicrobial effect, in vitro, of gutta-percha points containing root canal medications against yeasts and Enterococcus faecalis. Oral Surg Oral Med Oral Pathol Oral Radiol Endod. 2006;102:410-6.

72- Pacios MG, Silva C, López ME, Cecilia M. Antibacterial action of calcium hydroxide vehicles and calcium hydroxide pastes. J Invest Clin Dent. 2012;3:264-70.

73- Papia E, Larsson C, du Toit M, Vult von Steyern P. Bonding between oxide ceramics and adhesive cement systems: a systematic review. J Biomed Mater Res B Appl Biomater. 2014;102:395-413.

74- Peters L, Wesselink P, Moorer W. The fate and the role of bacteria left in root dentinal tubules. Int Endod J. 1995;28:95-9.

75- Piovesani JF, Semenoff-Segundo A, Pedro FL, Borges ÁH, Neves ANP, Mamede Neto I, et al. Capacidade antimicrobiana de diferentes medicações intracanais sobre o Enterococcus faecalis. Dent Press Endod. 2012;2:53-8.

76- Podbielski A, Boeckh C, Haller B. Growth inhibitory activity of gutta-percha points containing root canal medications on common endodontic bacterial pathogens as determined by an optimized quantitative in vitro assay. J Endod. 2000;26:398-403.

77- Podbielski A, Spahr A, Haller B. Additive antimicrobial activity of calcium hydroxide and chlorhexidine on common endodontic bacterial pathogens. J Endod. 2003;29:340-5. 
78- Portenier I, Haapasalo H, Rye A, Waltimo T, Ørstavik D, Haapasalo M. Inactivation of root canal medicaments by dentine, hydroxylapatite and bovine serum albumin. Int Endod J. 2001;34:184-8.

79- Portenier I, Waltimo T, Ørstavik D, Haapasalo M. The susceptibility of starved, stationary phase, and growing cells of Enterococcus faecalis to endodontic medicaments. J Endod. 2005;31:380-6.

80- Prabhakar A, Hadakar SG, Raju OS. Comparative evaluation of $\mathrm{pH}$ and antibacterial effect of various calcium hydroxide combinations on $\mathrm{E}$. faecalis and its effect on root strength: an in vitro study. Contemp Clin Dent. 2012;3:42-7.

81- Queiroz AM, Nelson-Filho P, Silva LA, Assed S, Silva RA, Ito IY. Antibacterial activity of root canal filling materials for primary teeth: zinc oxide and eugenol cement, Calen paste thickened with zinc oxide, Sealapex and EndoREZ. Braz Dent J. 2009;20:290-6. 82- Ravishanker P, Rao CS. Antimicrobial efficacy of four calcium hydroxide formulations and chlorhexidine gel using agar diffusion model [online]. Internet ] Dent Sci. 2009;8(1). Available from: http://ispub.com/IJDS/8/1/7932.

83- Roach RP, Hatton JF, Gillespie MJ. Prevention of the ingress of a known virulent bacterium into the root canal system by intracanal medications. J Endod. 2001;27:657-60.

84- Safavi KE, Spngberg LSW, Langeland K. Root canal dentinal tubule disinfection. J Endod. 1990;16:207-10.

85- Schäfer E, Bössmann K. Antimicrobial efficacy of chlorhexidine and two calcium hydroxide formulations against Enterococcus faecalis. J Endod. 2005;31:53-6.

86- Schirrmeister JF, Liebenow AL, Braun G, Wittmer A, Hellwig E, Al-Ahmad A. Detection and eradication of microorganisms in rootfilled teeth associated with periradicular lesions: an in vivo study. J Endod. 2007;33:536-40.

87- Shahravan A, Haghdoost AA, Adl A, Rahimi H, Shadifar F. Effect of smear layer on sealing ability of canal obturation: a systematic review and meta-analysis. J Endod. 2007;33:96-105.

88- Shuping GB, Orstavik D, Sigurdsson A, Trope M. Reduction of intracanal bacteria using nickel-titanium rotary instrumentation and various medications. J Endod. 2000;26:751-5.

89- Silveira CF, Cunha RS, Fontana CE, Martin AS, Gomes BP, Motta $\mathrm{RH}$, et al. Assessment of the antibacterial activity of calcium hydroxide combined with chlorhexidine paste and other intracanal medications against bacterial pathogens. Eur J Dent. 2011;5:1-7. 90- Siqueira JF Jr, Batista MM, Fraga RC, Uzeda M. Antibacterial effects of endodontic irrigants on black-pigmented gram-negative anaerobes and facultative bacteria. J Endod. 1998;24:414-6.

91- Siqueira JF Jr, de Uzeda M. Intracanal medicaments: evaluation of the antibacterial effects of chlorhexidine, metronidazole, and calcium hydroxide associated with three vehicles. J Endod. 1997;23:167-9.

92- Siqueira JF Jr, de Uzeda M, Fonseca ME. A scanning electron microscopic evaluation of in vitro dentinal tubules penetration by selected anaerobic bacteria. J Endod. 1996;22:308-10.

93- Siqueira JF Jr, Lopes $\mathrm{H}$. Mechanisms of antimicrobial activity of calcium hydroxide: a critical review. Int Endod J. 1999;32:361-9.

94- Siqueira JF Jr, Paiva SS, Rôças IN. Reduction in the cultivable bacterial populations in infected root canals by a chlorhexidine-based antimicrobial protocol. J Endod. 2007;33:541-7.

95- Siren EK, Haapasalo MP, Waltimo TM, Orstavik D. In vitro antibacterial effect of calcium hydroxide combined with chlorhexidine or iodine potassium iodide on Enterococcus faecalis. Eur ] Oral Sci. 2004;112:326-31

96- Sjögren U, Figdor D, Spångberg L, Sundqvist G. The antimicrobial effect of calcium hydroxide as a short-term intracanal dressing. Int Endod J. 2007;24:119-25.

97- Souza-Filho FJ, Soares AJ, Vianna ME, Zaia AA, Ferraz CC, Gomes BP. Antimicrobial effect and $\mathrm{pH}$ of chlorhexidine gel and calcium hydroxide alone and associated with other materials. Braz Dent J. 2008;19:28-33.

98- Sukawat C, Srisuwan T. A comparison of the antimicrobial efficacy of three calcium hydroxide formulations on human dentin infected with Enterococcus faecalis. J Endod. 2002;28:102-4.
99- Sundqvist G. Ecology of the root canal flora. J Endod. 1992; 18:427-30.

100- Sundqvist G, Figdor D, Persson S, Sjögren U. Microbiologic analysis of teeth with failed endodontic treatment and the outcome of conservative re-treatment. Oral Surg Oral Med Oral Pathol Oral Radiol Endod. 1998;85:86-93.

101- Tronstad L, Andreasen JO, Hasselgren G, Kristerson L, Riis I. $\mathrm{pH}$ changes in dental tissues after root canal filling with calcium hydroxide. J Endod. 1981;7:17-21.

102- Turk BT, Sen BH, Ozturk T. In vitro antimicrobial activity of calcium hydroxide mixed with different vehicles against Enterococcus faecalis and Candida albicans. Oral Surg Oral Med Oral Pathol Oral Radiol Endod. 2009;108:297-301

103- Vaghela DJ, Kandaswamy D, Venkateshbabu N, Jamini N, Ganesh A. Disinfection of dentinal tubules with two different formulations of calcium hydroxide as compared to $2 \%$ chlorhexidine: as intracanal medicaments against Enterococcus faecalis and Candida albicans: an in vitro study. J Conserv Dent. 2011;14:182-6. 104- Valera MC, Salvia AC, Maekawa LE, Camargo SE, Carvalho CA, Camargo $\mathrm{CH}$, et al. Antimicrobial analysis of chlorhexidine gel and intracanal medicaments against microorganisms inoculated in root canals. Minerva Stomatol. 2010;59:415-21.

105- Valera MC, Silva KC, Maekawa LE, Carvalho CA, Koga-Ito CY,

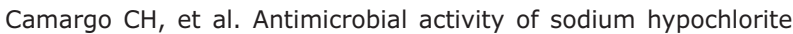
associated with intracanal medication for Candida albicans and Enterococcus faecalis inoculated in root canals. J Appl Oral Sci. 2009;17:555-9.

106- Van der Waal SV, Jiang LM, de Soet JJ, van der Sluis LW, Wesselink PR, Crielaard W. Sodium chloride and potassium sorbate: a synergistic combination against Enterococcus faecalis biofilms: an in vitro study. Eur J Oral Sci. 2012;120:452-7.

107- Vanajasan PP, Dhakshinamoorthy M, Rao CS. Factors affecting the bond strength of self-etch adhesives: a meta-analysis of literature. J Conserv Dent. 2011;14:62-7.

108- Vianna ME, Gomes BP. Efficacy of sodium hypochlorite combined with chlorhexidine against Enterococcus faecalis in vitro. Oral Surg Oral Med Oral Pathol Oral Radiol Endod. 2009;107:585-9.

109- Vianna ME, Horz HP, Conrads G, Feres M, Gomes BP. Comparative analysis of endodontic pathogens using checkerboard hybridization in relation to culture. Oral Microbiol Immunol. 2008;23:282-90.

110- Vidya S. Old and novel intracanal medicaments against Candida albicans. Aust Dent J. 2007;52:257.

111- Vivacqua-Gomes N, Gurgel-Filho ED, Gomes BP, Ferraz CC, Zaia AA, Souza-Filho FJ. Recovery of Enterococcus faecalis after single- or multiple-visit root canal treatments carried out in infected teeth ex vivo. Int Endod J. 2005;38:697-704.

112- Wang CS, Arnold RR, Trope M, Teixeira FB. Clinical efficiency of $2 \%$ chlorhexidine gel in reducing intracanal bacteria. J Endod. 2007;33:1283-9.

113- Wang Kou LV, Siguas Meneses DM. Comparative study of the antibacterial effects of the association of chlorhexidine $2 \%$ solution, calcium hydroxide, points of calcium hydroxide and points of chlorhexidine against Enterococcus faecalis. Kiru. 2007;4:14-6. 114- Zehnder M, Grawehr M, Hasselgren G, Waltimo T. Tissuedissolution capacity and dentin-disinfecting potential of calcium hydroxide mixed with irrigating solutions. Oral Surg Oral Med Oral Pathol Oral Radiol Endod. 2003;96:608-13.

115- Zerella JA, Fouad AF, Spångberg LS. Effectiveness of a calcium hydroxide and chlorhexidine digluconate mixture as disinfectant during retreatment of failed endodontic cases. Oral Surg Oral Med Oral Pathol Oral Radiol Endod. 2005;100:756-61. 